Trakya Eğitim Dergisi

Cilt 9, Sayı 3

Eylül 2019, 580-589

Geliș Tarihi: 23.01.2019

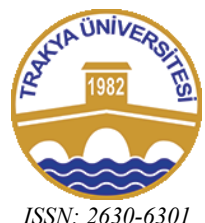

ISSN: 2630-6301
Trakya Journal of Education

Volume 9, Issue 3

September 2019, 580-589

Doi: $10.24315 /$ tred.516756

Yayına Kabul Tarihi: 26.05.2019

\title{
Sınıflarında Kaynaştırma Öğrencisi Olan ve Olmayan 4-6 Yaş Çocuklarının Bakış Açısı Alma Becerilerinin Belirlenmesi ${ }^{1}$
}

\author{
Examining the Hierarchic Structures of Emotions Experienced by Teachers and \\ Administrators in the School
}

Meral TANER DERMAN ${ }^{2}$, Yelda CIVCIK ${ }^{3}$, Sema BAYKARA $^{4}$, Sıla ÖZÇINAR $^{5}$,

\begin{abstract}
Öz: raştırmanın temel amacı sınıflarında kaynaştırma öğrencisi olan ve olmayan 4-6 yaş çocuklarının bakış açısı alma becerilerinin belirlenmesidir. Araştırma Bursa ilinde önceden belirlenen dört anaokulundaki 10 sinıfta yürütülmüştür. Sınıfında kaynaştırma öğrencisi bulunan 100 çocuk, sınıfında kaynaştırma öğrencisi bulunmayan 100 çocuk olmak üzere toplam 200 öğrenciye 'Bakış Açısı Alma Becerisi Testi' uygulanmıştır. Araştırma sonucunda kaynaştırma eğitimi alan bir çocuğun bulunduğu sınıftaki ile kaynaştırma eğitimi alan bir çocuğun bulunmadığı sınıftaki çocuklar arasında bakış açısı alma becerisi arasında istatistiksel olarak anlamlı bir farklılık olmadığ saptanmıştır. Çocukların bakış açısı alma becerilerinin cinsiyete göre farklılaşmadığı ve dört yaşındaki çocukların bakış açısı alma becerilerinin, 5 ve 6 yaşa göre daha düşük olduğu belirlenmiştir.
\end{abstract}

Anahtar sözcükler: Empati, bakış açısı alma, kaynaştırma, kaynaştırma öğrencisi

\begin{abstract}
The purpose of the study is the identification of 4-6 years old children's perspective taking skills in preschool with and without inclusive students. The research was conducted in four kindergartens in Bursa. A total of 200 students, including 100 children with inclusive students in the class and 100 children with no inclusive students in the class. The test of the research were chosen as Perspective Taking Test for Children (PTC). As a result of the research, it was determined that there was no statistically significant difference between the viewpoint acquisition skill of a class with a inclusive student and a class without a inclusive student. It has been determined that the ability of children to perspective taking is not differentiated by sex. It was determined that children's ability to perspective taking is lower for children aged four years than for age 5 and 6 years.
\end{abstract}

Keywords: Empathy, perspective taking, inclusive, inclusive students

\section{EXTENDED SUMMARY}

\section{Introduction}

Empathy is putting oneself into other people's place understanding their emotions and thoughts correctly, looking through the events from their perspective and interiorising those events. Empathy has an important place in preventing the communication conflicts and communication problems (Dökmen, 2013). By means of empathy human relations and communication develop. The problems among people can decrease and be solved in progress of time (Keski and Aykaç, 2014). Empathic understanding has features such as providing people establish close relationships with each other and simplifying communication in every aspect of daily life (Özbek, 2004). Accordingly empathic skill has an important role in establishing healthy person to person relationships (Sal1, 2013). For developing empathy taking roles and 'the skill of perspective taking' are obligatory (Dökmen, 2013). Perspective taking is providing the understanding the situations, thoughts and emotions of other people and it is considered as the skill of comprehending the oral and visual point of views simultaneously regarding the world.

Perspective taking is a perception that requires the children reveal their information and the others' (Heagle and Rehfeldt, 2006). The process of perspective taking enables the children understand others and give empathic answers by this way. The skill of perspective taking has three dimensions such as perceptual, cognitive and emotional. Perceptual perspective taking is stated as the inference of someone in terms of what is seen from someone else's perspective; cognitive perspective taking is considered as

\footnotetext{
1 Bu makale 29-31 Mart 2018 tarihlerinde Bursa'da düzenlenen 1. Uluslararası Temel Eğitim Kongresinde sözlü bildiri olarak sunulmuştur.

2 Dr. Öğr. Üyesi, Bursa Uludağ Üniversitesi Eğitim Fakültesi Temel Eğitim Bölümü, Okulöncesi Eğitimi Anabilim Dal1, mtaner@uludag.edu.tr ORCID: 0000-0002-5212-3905

3 Öğretmen, Milli Eğitim Bakanlığı, yyeellddaa9797@gmail.com ORCID: 0000-0002-4240-4017

4 Öğretmen, Milli Eğitim Bakanlığı, baykara.sema95@gmail.com ORCID: 0000-0002-2694-454X

5 Öğretmen, Milli Eğitim Bakanlığı, silaozcinar20@gmail.com ORCID: 0000-0001-8400-0806
} 
being aware of what others think; and emotional perspective taking is stated as evaluating or understanding the emotion of someone else (Aslan and Köksal Akyol, 2016).

Inclusive education is educating the children that have special needs together with the children, who show normal development in educational environment and it provides benefit for the children in both groups (Kurcaali-İftar, 1998; Villa and Thousand 1995). Inclusive education helps the children that have special needs to adapt the community. When it is carried out appropriately for the conditions it can not only be beneficial for the child who has special needs and also for the other children in the classroom, educator and for the families as well (Metin, 2012).

The main purpose of this research is the investigation of the perspective taking skills of the preschool period children who have inclusive classmates and of those who do not have inclusive classmates. Since it is aimed to investigate the perspective taking skills of the preschool period children, who have inclusive classmates and the children, who do not have inclusive classmates; descriptive scanning model, which is one of the quantitative research methods, was used in the research.

The sample of the research consists of 106 female and 94 male totally 200 students from 10 classroom in four nursery schools that were chosen occasionally in the city of Bursa. Whereas there were inclusive students in the 5 classrooms out of 10 classrooms included in the research, there were not inclusive students in the other five classrooms.

For gathering the data in order to scale the perspective taking skills of the children the Perspective Taking Test for Children, which was developed by Aslan and Köksal Akyol (2016), was used. The data obtained at the end of the application was analysed using quantitative statistics techniques. In order to see whether there was a statistical significant difference according to the classroom including and not including inclusive students and gender; $t$ test was carried out. In order to understand whether there was a statistical significant difference among the age groups variance analysis was used.

It was deduced that this difference within the educational environment does not affect the perspective taking skills of the students, whose classrooms involve and do not involve inclusive students.

According to Mental Development Theory of Piaget (2004) it is known that the children within the preschool period are egocentric. Within the egocentric period the children cannot recognize that other people can possess a perspective different from theirs. Accordingly it is thought that the reason why there was not a difference between the children who have inclusive classmates and the children who do not have inclusive classmates, in terms of perspective taking skills resulted from the fact that these children were in the in the egocentric period.

As a result of the research it was determined that the children who have inclusive classmates were not different from the children who do not have inclusive classmates in terms of perspective taking skills. It was also determined that perspective taking skills do not differentiate according to gender and the perspective taking skills of the children at the age of four were lower compared to the children at the age of 5 and 6 .

It was determined that the perspective taking skills of the children in whose classroom there were inclusive students and the children in whose classrooms there were not inclusive students were not different from each other. Especially activities regarding the development of empathy skills of the children should be included within the classroom in order to enable the children, in whose classroom there are inclusive students, to develop a more positive perspective for their classmates. This research is bounded by the comparison of the perspectives of the children who have inclusive classmates and the children who do not have inclusive classmates. The research can also be planned as the perspective taking of the children who have inclusive students in their classroom and the students who do not have inclusive students in their classroom together with the comparison of the empathy skills.

İletişim, hayatın tüm alanlarında insanlar için büyük bir önem arz etmektedir. Duygular, düşünceler, istek ve ihtiyaçların karşı tarafa iletebilmesi için tüm canlılar arasında iletişim şarttır, fakat bireylerin birbirini anlaması için tek başına yeterli değildir. Bu konuda devreye günlük yaşantıda kullanılan, duyulan ve belki de doğru kullanıldığı sanılan empati kavramı girmektedir.

Bireyin, kendisini karşısındaki başka bir kişinin yerine koyarak, onun duygu ve düşüncelerini doğru bir şekilde anlaması, olaylara onun gözünden bakması ve içselleştirmesidir. Empati, iletişim çatışmalarını ve iletişim problemlerini engellemede büyük bir yere sahiptir (Dökmen, 2013). Empati insanların ilişkilerini ve iletişimlerini geliştirmeyi sağlayarak insanlar arasındaki sorunların azalmasını ve zamanla çözülmesine katkı sağlar (Keski ve Aykaç, 2014).

Empatik anlayış günlük hayatın her alanında insanları birbiri ile yakın ilişsi kurmasını sağlama, iletişimi kolaylaştırma gibi özelliklere sahiptir (Özbek, 2004). Empati becerisi, kişiler 
arası sağlıklı iletişim kurulmasını sağlar (Salı, 2013). Empati becerisine sahip olan kişilerin hoşgörülü, diğer insanlarla iyi geçinen, sevecen, işbirliği ve yardımlaşmada daha iyi olan, kendini olduğu gibi kabul edebilen, arkadaşlık ilişkileri geliştirmede daha başarılı ve daha paylaşımcı kişiler oldukları; empati kuramayan insanların ise diğer insanların duygularına önem vermedikleri tespit edilmiştir (Huneryager and Heckmann 1967; Muslu Köseoğlu, 1994; Roberts ve Strayer, 1996). Empatik becerilerinin artışının sorun davranışları azaltmada etkili olduğu belirtilmektedir (Gürtunca, 2013). Empati eğitimi alan kişilerin saldırganlık ve anti sosyal davranışlarının azaldığı, sosyal uyumlarının ise arttığı belirlenmiştir (Yüksel, 2004).

Empati kurabilmek için bakış açısı alma becerisine sahip olmak gerekmektedir (Dökmen, 2013). Bakış açısı alabilme, dünyadaki diğer insanlara yönelik sözel ve görsel bakış açılarının eş zamanlı olacak şekilde kavrama yeteneği olarak değerlendirilmektedir. Bu yetenek, durumları, karşıdaki kişinin bakış açısından, onun fikirleriyle ve duygularıyla anlayabilmeyi sağlamaktadır. Kısaca bakış açısı alma; bir durumu başka bir kişinin bakış açısından görerek anlamak olarak tanımlanabilir (Şener, 1996). Dünyayı başka bir noktadan hayal etme ya da kendini başka birinin ayakkabılarında hayal etme süreci olarak da tanımlanmaktadır (Galinsky, Ku ve Wang, 2005). Empati karşımızdaki kişinin duygu, düşünce ve hislerini anlamak iken bakış açısı alma becerisi, bu duygu düşünce ve hislerle karşımıza çıkan durumu değerlendirebilme becerisidir. Bakış açısı alabilen bireyler kendini karşısındakinin yerine koyabilir ve problem durumunda çözümler üretebilir. Bakış açısı alabilen kişiler, karşısındakinin düşüncelerini daha kolay anlayabildikleri için sosyal etkileşim yönünden de diğer bireylere kolaylık sağlar (Dixon ve Moore, 1990).

Bakış açısı alma, bireyin kendisindeki ve başkalarındaki bilgileri ifade edebilmeyi şart koyan bir algı olarak değerlendirilmektedir (Heagle ve Rehfeldt, 2006). Bu beceri çocuklarda, genellikle 4 yaş civarında ortaya çıkmaktadır (Baron-Cohen, Leslie ve Frith, 1985). Algısal, bilişsel ve duygusal bakış açısı alma şeklinde üç boyutlu olan bakış açısı alma becerisinde süreç, çocukların başkalarını anlamaları ve bu sayede de empatik cevaplar vermelerini sağlama şeklinde olmaktadır. Algısal bakış açısı alma, birinin bir başka kişinin bakış açısından bakıp görebildiklerine yönelik çıkarımıdır. Bilişsel bakış açısı alma, başka birinin ne düşündüğünü fark edebilme ile alakalıdır. Duygusal bakış açısı alma, başka bir kişinin sahip olduğu duyguyu değerlendirebilme veya anlama olarak ifade edilmektedir (Aslan ve Köksal Akyol, 2016).

Kaynaştırma eğitimi, özel gereksinimli çocukların normal gelişim gösteren akranlarıyla beraber genel eğitim ortamlarında destek hizmetleri alarak eğitilmesidir. Bu kaynaştırma eğitimiyle, özel gereksinimli çocukların normal gelişim gösteren akranlarıyla sosyal açıdan birlikteliklerini amaçlamakla birlikte, bu eğitim uygulamasının her iki gruptaki çocuklara da yarar sağlaması beklenmektedir (Sucuoğlu ve Kargın, 2008; Kırcaali-İftar, 1998; Villa ve Thousand 1995). Kaynaştırma eğitimi, özel gereksinimli çocukların topluma uyum sağlamasına ve toplumla bütünleşmesine yardım etmektedir. Kaynaştırma eğitimi, olması gerektiği şekilde uygulandığında özel gereksinimli çocuk için faydalı olduğu kadar sınıfındaki normal gelişim gösteren diğer çocuklar, eğitimciler ve aileler için de faydalı olacağı ifade edilmektedir (Metin, 2012).

Kaynaştırma eğitimi sürecinde normal çocukların özel gereksinimli çocuklara karşı koşulsuz kabulünün, yardımlaşma becerisinin, ortak yaşam, hoşgörü, demokratik ilkeler ve ahlaki anlayışlarının gelişmesi beklenmektedir. Bu çocukların bireysel farklılıkları benimsemelerinden dolayı kendilerinden farklı gelişim özellikleri gösteren akranların doğal karşıladıkları ve onlara saygı duymayı öğrendikleri belirtilmektedir (Kırcaali-İftar ve Batu, 2005). Bu eğitimi alan özel gereksinimli çocuklarla aynı ortamı paylaşan çocukların, empati kurma, yetersizliklerinin farkında olma, kabul etme ve bunları telafi etmeye yönelik çabaları ile model olma, sorumluluk alma ve liderlik becerileri gelişmektedir (Essa, 1999; Göksu ve Çevik, 2004). Özellikle, kaynaştırma eğitimi verilen sınıfların etkileşimli ve işbirliğine dayalı doğası nedeniyle, çocukların empati becerilerinin arttı̆g belirtilmektedir (Maine, 2013). Ayrıca, aileler ve öğretmenler de bireysel özellikleri farklı olsa da bütün çocukların ortak yönleri olduğunu görüp, kendi çocuklarının güçlü ve zayıf yönlerini fark edebilmektedirler (Essa, 1999). Bu hizmet ile özel gereksinimli bireylerin toplum ile kaynaşması sağlanırken, diğer bireylerde de farkındalık oluşmaktadır.

MEB'in Özel Eğitim hizmetleri Yönetmeliğinde ise kaynaştırma eğitimi, "özel eğitim ihtiyacı olan bireylerin her tür ve kademe dediğer bireylerle karş1lıklı etkileşim içinde bulunmalarını ve eğitim amaçlarını en üst düzeyde gerçekleştirmelerini sağlamak amacıyla bu bireylere destek eğitim hizmetleri de sunularak akranlarıyla birlikte tam zamanlı ya da özel 
eğitim sınıflarında yarı zamanlı olarak verilen eğitim” olarak tanımlanmaktadır (MEB, 2018). Kaynaştırma eğitimi alan özel gereksinimli çocukların, normal gelişim gösteren çocuklarla etkileşme, iletişim kurma, birlikte çalışma, arkadaşlık geliştirme ve birbirilerine yardımcı olma gibi becerileri de öğrendikleri ifade edilmektedir (Stainback ve Stainback, 1992: Akt. Batu, Kırcaali-İftar ve Uzuner, 2004). Kaynaştırma eğitimi alan özel gereksinimli çocukların gelişim düzeyleri ve beceri gerektiren çalışmalarda beceri düzeyleri bakımından, özel eğitim sınıflarına devam eden özel gereksinimli çocuklardan daha iyi oldukları, dil ve beceri gelişiminin hızlandığı ifade edilmektedir (Diamond ve Hestenes, 1996; Ersoy ve Avc1, 2000). Kaynaştırma eğitiminin başarıya ulaşması için, özel gereksinimli çocukların, normal gelişim gösteren çocuklar tarafından sosyal olarak kabul edilmeleri en önemli etkenlerden birisidir. Sosyal kabul, özel gereksinimli öğrencilerin sosyalleşmesi, onların kendilerini kabul etmesi, değerli ve yeterli görmesi için çok önemlidir (Arslan, 2010; Civelek, 1990). Normal gelişim gösteren akranlarının kaynaştırma eğitimi alan çocukları anlaması ve bu çocuklara nasıl yardımcı olabileceklerini öğrenmesi, kaynaştırma eğitimi alan çocuklara yönelik farkındalık oluşumunun ve sosyal kabulünün önkoşulu olduğu belirtilmektedir (Bek, Gülveren ve Başer, 2009).

Kaynaştırma eğitimi verilen sınıflarda çocuklar, çeşitlilik ve farklılı̆̆ deneyimleme firsatı bulmaktadırlar (Specht, 2013). Bireylerin, günlük yaşamlarında başkalarıyla sağlıklı ve başarılı ilişkiler kurabilmeleri için, kendisi ve başkalarını doğru olarak anlayabilmeleri ve kabul etmeleri gerekmektedir. Diğerlerinin fikirlerine ve düşüncelerine saygı göstermek ve hoşgörülü olmak demokratik bir toplum oluşturmak açısından oldukça yararlıdır (Yüksel, 2004). Bakış açısı alma becerisi, sosyal uyum ve anlayış için çok önemli bir beceridir. Bakış açısı alma becerisi, kendisi gibi olmayanların bakış açısıyla dış dünya hakkında düşünmeye teşvik ettiği için, empati becerisini arttırmakta ve önyargılar ile basmakalıp düşünceleri azaltmaya yardımcı olmaktadır (Galinsky ve Moskowitz, 2000; Kubota ve Ito, 2014). Ayrıca, bakış açısı alma becerisinin de kaynaştırma eğitimi sürecinin daha başarılı olmasını sağladığı belirtilmektedir (Baskerville, 2011). Dolayısıyla akranları tarafından sosyal olarak kabul edilme aşamasında, bakış açısı alma becerileri bu kabullenmeyi etkilemektedir. Bakış açısı alma becerisi gelişmemiş olan okul öncesi dönem çocukları kendinden farklı olan bireylere karşı hoşgörülü ve anlayışlı olmada zorluk yaşayabilirler. $\mathrm{Bu}$ araştırma, kaynaştırma eğitimi alan ve kaynaştırma eğitimi almayan öğrenci ile aynı sınıfı paylaşan okulöncesi dönem çocuğunun, bakış açısı alma becerisinin ne durumda olduğunu görmek açısından önem teşkil etmektedir. Bu nedenle bu araştırmanın temel amacı sınıflarında kaynaştırma öğrencisi olan ve olmayan 4-6 yaş çocuklarının bakış açısı alma becerilerinin incelenmesidir. Bu amaç doğrultusunda aşağıdaki sorulara yanıt aranmıştır:

1. Kaynaştırma öğrencisi olan ve olmayan sınıflardaki 4-6 yaş çocukların bakış açısı alma becerileri arasında fark var midir?

2. 4-6 yaş çocuklarım bakış açısı alma becerileri cinsiyete göre değişmekte midir?

3. 4-6 yaş çocukların bakış açısı alma becerileri yaşa göre değişmekte midir?

\section{YÖNTEM}

\section{Araştırma Modeli}

Sınıflarında kaynaştırma öğrencisi olan ve olmayan 4-6 yaş çocuklarının bakış açısı alma becerilerinin incelenmesi amaçlandığ 1 için araştırmada nicel araştırma yöntemlerinden betimsel tarama modeli kullanılmıştır. Geçmişte veya şu anda var olan durum herhangi bir şekilde değiştirilmeden olduğu haliyle betimlemeyi ve durum, birey ya da nesnenin olduğu gibi tanımlanmaya çalışıldığı modeller tarama modeli olarak ifade edilmektedir (Karasar, 2002).

\section{Evren ve Örneklem}

Araştırmanın evrenini Bursa ilinde okulöncesi eğitimi alan çocuklar oluşturmaktadır. Araştırmanın örneklemini ise Bursa ilinde tesadüfi olarak seçilen dört anaokulundaki 10 sınıftan 106 kız 94 erkek olmak üzere toplam 200 öğrenci oluşturmaktadır. Araştırmaya dahil edilen 10 
sınıfın beş sınıfında kaynaştırma öğrencisi bulunurken, beş sınıfında kaynaştırma öğrencisi bulunmamaktadir.

Tablo 1: Örneklem grubundaki çocukların dağılımı

\begin{tabular}{|c|c|c|c|c|}
\hline & & & & \\
\hline & & $\mathrm{K} 1 \mathrm{z}$ & Erkek & Toplam \\
\hline & 4 yaş & 7 & 5 & 12 \\
\hline & 5 yaş & 33 & 31 & 64 \\
\hline Kaynaştırma ogrencisı olan sınıf & 6 yaş & 14 & 10 & 24 \\
\hline & Toplam & 54 & 46 & 100 \\
\hline & 4 yaş & 16 & 21 & 37 \\
\hline & 5 yaş & 23 & 18 & 41 \\
\hline Kaynaştirma ogrencisı olmayan sinıt & 6 yaş & 13 & 9 & 22 \\
\hline & Toplam & 52 & 48 & 100 \\
\hline
\end{tabular}

\section{Veri Toplama Araçları ve Verilerin Toplanması}

Verilerinin toplanması aşamasında, Aslan ve Köksal Akyol (2016) tarafından geliştirilen Çocuklar için Bakış Açısı Alma Testi (ÇBT) kullanılmıştır. Veri toplama aşamasında; uygulama yapılacak okulların yönetici ve öğretmenleri ile görüşülerek izin alınmış ve araştırma hakkında gerekli bilgiler verilmiştir. Uygulama sakin bir ortamda çocuklarla birebir olarak yapılmıştır. Resimler aracılığı ile bir oyun oynayacağımız söylenerek çocukların ilgileri test üzerine çekilmiştir. Uygulamalar, bireysel olarak okulun boş bir sınıfinda gerçekleştirilmiştir. Daha sonra çocuklara 24 maddeden oluşan Çocuklar İçin Bakış Açısı Alma Testi (ÇBT) araştırmacılar tarafından uygulanmıştır. Çocuklara ölçeğe ait resimler sırasıyla ve teker teker gösterilmiştir. Çocuklar resimleri verilen sürelerde incelemiş ve yorum yapmışlardır. Yapılan yorumlara ve testin değerlendirme şekline uygun olarak 1-0 şeklinde puanlar verilmiştir.

\section{Çocuklar için bakış açısı alma testi (BAT)}

Test, algısal bakış açısı alma (4 madde), bilişsel bakış açısı alma (4 madde) ve duygusal bakış açısı alma (16 madde) olmak üzere üç boyutlu ve toplam 24 maddeden oluşan bir testtir.

\section{Algısal bakış açısı alma boyutu}

Çocukların günlük yaşamlarında karşılaşabilecekleri durumlara yönelik dört maddeden meydana gelmektedir. Çocuğun, resimde bulunan karakterin bakış açısından bakması ve ne gördüğünü tahmin etmesi gerekmektedir. Değerlendirme yapılırken, çocuk eğer doğru tahmin ediyorsa 1 puan, yanlış tahmin ediyorsa 0 puan verilmektedir.

\section{Bilişsel bakış açısı alma boyutu}

Çocuğa çeşitli olayların yer aldığı ve en çok 5-6 karttan oluşturulmuş hikâye kartları gösterilir. Hikaye kartlarındaki olaylar anlatıldıktan sonra can alıcı noktayı, olayın nedenini ya da sonucunu içeren kart çıkarılır. Çocuğa, "Şimdi sınıfından bir arkadaşını buraya çağırsak, resimlere bakarak burada ne olduğunu (neden böyle olduğu ya da sonunda ne olduğunu) sorsak, ne der?" diye sorulur. Değerlendirme yapılırken, çocuk eğer doğru bakış açısıyla cevap veriyorsa 1 puan, yanlış cevap veriyorsa 0 puan verilir.

\section{Duygusal bakış açısı alma boyutu}

Çocukların yaşamlarında karşılaşabilecekleri mutlu olma, üzülme, kızma ve korkma duygularını içeren resimler bulunmaktadır. Örneğin çizdiği resim arkadaşı tarafından bilerek yırtılan bir çocuk, dondurmasını yere düşüren bir çocuk, annesinin oyuncak aldığı bir çocuk vb. Resimdeki ana karakterin yüzü boş bırakılır. Bu şekilde çocuğun, ana karakterin yüz ifadesinden duygusunu tahmin etmesi engellenmeye çalışılmıştır. Uygulama sırasında farklı duyguları içeren resimler karışık bir sırada çocuğa gösterilmektedir. Her resimde geçen olay kısaca betimlenmekte ve ana karakterin ne hissetmiş olabileceği sorulmaktadır. Eğer çocuk, resimdeki 
ana karakterin duygusunu (mutlu olma, üzülme, kızma, korkma) doğru ifade ederse 1 puan, yanlış ifade ederse 0 puan almaktadır. Çocuklar için bakış açısı alma testinden alınabilecek en yüksek puan 24, en az puan ise 0'dır.

ÇBT'nin ölçüt dayanaklı geçerliği için Köksal Akyol ve Aslan (2014) tarafindan geliştirilen Çocuklar İçin Empati Ölçeği (ÇEMÖ) $(r=.80)$ ile Şener (1996) tarafından geliştirilen Bakış Açısı Alma Testi (BAT) (r=.73) kullanılmıştır. ÇBT'nin iç tutarlılık güvenirliği için KR20 değeri .71, test-tekrar test güvenirlik katsayısı ise .91 olarak bulunmuştur (Aslan ve Köksal Akyol, 2016). Bu değerler, testin çocukların bakış açısı alma becerilerini ölçmeye yönelik yeterli güvenirlik ve geçerliğe sahip olduğunu göstermektedir (Büyüköztürk, 2002; Turgut, 2012; Özdamar, 2004; Akbulut, 2010).

\section{Verilerin Analizi}

Araştırmanın verileri analiz edilirken nicel istatistik tekniklerinden yararlanılmıştır. Kaynaştırma öğrencisi olan ve olmayan sınıfa ve cinsiyete göre istatistiksel bir farklılık olup olmadığını görmek amacıyla $\mathrm{t}$ testi, yaşa göre gruplar arasında istatistiksel farklılık olup olmadığını görmek amacıyla ise varyans analizi yapılmıştır.

\section{BULGULAR ve TARTIŞMA}

Bu bölümde sınıflarında kaynaştırma öğrencisi olan ve olmayan 4-6 yaş çocuklarının bakış açısı alma becerileri, cinsiyete ve yaşa göre incelenerek elde edilen bulgular tablolar halinde özetlenmiştir.

Sınıflarında kaynaştırma öğrencisi bulunan ve bulunmayan çocukların bakış açısı alma beceri düzeyleri arasındaki farkı görmek amacıyla yapılan t testi sonuçları Tablo 2'de verilmiştir. Tablo 2: Sınıflarında kaynaştırma öğrencisi bulunan ve bulunmayan çocukların bakış açısı alma testinden aldıkları puanlarına ilişkin t testi sonuçları

\begin{tabular}{lccccccc}
\hline \multicolumn{1}{c}{ Öğrenci tipi } & $\mathrm{n}$ & Ortalama & Std. sapma & Std. Hata & $\mathrm{sd}$ & $\mathrm{t}$ & $\mathrm{p}$ \\
\hline Kaynaştırma öğrencisi bulunmayan sınıf & 100 & 15,65 & 3,30 & 0,33 & \multirow{2}{*}{198} & \multirow{2}{*}{0,44} & \multirow{2}{*}{0,66} \\
Kaynaştırma öğrencisi bulunan sınıf & 100 & 15,45 & 3,12 & 0,31 & & \\
\hline
\end{tabular}

Tablo 2'ye göre kaynaştırma öğrencisi bulunan sınıfın bakış açısı alma testi puan ortalaması 15,45 iken, kaynaştırma öğrencisi bulunmayan sınıfın bakış alma testi puan ortalaması 15,65'tir. Tablo incelendiğinde kaynaştırma öğrencisi bulunan sınıflar ile kaynaştırma öğrencisi bulunmayan sinıflar arasında istatistiksel olarak anlamlı fark bulunmamaktadır ( $\mathrm{p}>0.05) . \mathrm{Bu}$ sonuca bakılarak sınıflarında kaynaştırma öğrencisi bulunan ve bulunmayan öğrencilerin, eğitim ortamlarındaki bu farklılığın bakış açısı alma becerilerini etkilemediği görüşüne varılmıştır.

Cinsiyete göre çocukların bakış açısı alma beceri düzeyleri arasındaki farkı görmek amacıyla yapılan $\mathrm{t}$ testi sonuçları Tablo 3 'te verilmiştir.

Tablo 3: Çocukların cinsiyetlerine göre çocukların bakış açısı alma testinden aldıkları puanlara ilişkin t testi sonuçları

\begin{tabular}{cccccccc} 
Cinsiyet & $\mathrm{n}$ & Ortalama & Std. sapma & Std.Hata & $\mathrm{Sd}$ & $\mathrm{t}$ & $\mathrm{p}$ \\
\hline K1z & 106 & 15,29 & 3,03 & 0,29 & \multirow{2}{*}{198} & \multirow{2}{*}{$-1,208$} & \multirow{2}{*}{0,23} \\
Erkek & 94 & 15,84 & 3,38 & 0,35 & & \\
\hline
\end{tabular}

Tablo 3 incelendiğinde kız öğrencilerin bakış açısı alma testi puan ortalamaları 15,29; erkek öğrencilerin bakış açısı alma testi puan ortalamaları ise 15,84 tür. Yapılan t testi sonucunda kız ve erkek öğrencilerin puan ortalamaları arasında istatistiksel olarak anlamlı bir farklılık olmadiğı saptanmıştır.

Yaşa göre çocukların bakış açısı alma beceri düzeyleri arasındaki farkı görmek amacıyla yapılan varyans analizi sonuçları Tablo 4, 5 ve 6'da verilmiştir. 
Tablo 4: Çocukların yaşlarına göre ÇBT'den aldıkları puanlar

\begin{tabular}{ccccc}
\hline Yaş & $\mathrm{n}$ & Ortalama & ss & Std. Hata \\
\hline 4 yaş & 49 & 14,37 & 3,35 & 0,48 \\
5 yaş & 105 & 15,77 & 3,14 & 0,31 \\
6 yaş & 46 & 16,30 & 2,92 & 0,43 \\
Toplam & 200 & 15,550 & 3,21 & 0,23 \\
\hline
\end{tabular}

Tablo 4'te görüldüğü gibi, 4 yaş grubun bakış açısı alma becerisi puan ortalaması 14,37; 5 yaş grubunun ortalaması 15,77; 6 yaş grubunun ortalaması ise hesaplanan ortalama 16,30 olarak bulunmuştur.

Tablo 5: Çocukların yaşlarına göre ÇBT'den aldıkları puanların varyans analizi sonuçları

\begin{tabular}{lccccc}
\hline & Kareler Ortalamas1 & sd & Ortalamanın Karesi & F & p \\
\hline Gruplar Aras1 & 99,859 & 2 & 49,93 & 5,05 & 0,007 \\
Grup İçi & 1945,641 & 197 & 9,88 & & \\
Toplam & 2045,500 & 199 & & & \\
\hline
\end{tabular}

Tablo 5'te, 4-6 yaş çocuklarının bakış açısı alma becerisi testinden aldıkları puanın yaşa göre anlamlı bir şekilde farklılaştığı görülmektedir $(\mathrm{F}=5,05, \mathrm{p}<.05)$. Bu bulguya göre, dört yaşındaki çocukların bakış açısı alma becerilerinin, 5 ve 6 yaşa göre daha düşük olduğu belirlenmiştir.

Hangi grupların ortalamaları arasında anlamlı fark olduğu Tukey analizi aşağıdaki Tablo 6'da verilmiştir.

Tablo 6: Farklılığın kaynağını görmek için yapılan Tukey Hoc Testi sonuçları

\begin{tabular}{ccccc}
\hline$(\mathrm{I})$ & $(\mathrm{J})$ & Ortalama Farkı $(\mathrm{I}-\mathrm{J})$ & Std. Hata & $\mathrm{p}$ \\
\hline 4 yaş & 5 yaş & $-1,40^{*}$ & 0,54 & 0,028 \\
& 6 yaş & $-1,94^{*}$ & 0,65 & 0,008 \\
5 yaş & 6 yaş & $-0,53$ & 0,56 & 0,604 \\
\hline
\end{tabular}

Tabloda görüldüğü gibi 4 yaş grubunun puanının, 5 ve 6 yaş gruplarının puanları arasında anlamlı bir farklılık saptanmıştır $(p<0.05) .5$ yaş ile 6 yaş arasındaki fark ise istatistiksel olarak anlamlı bulunmamıştır ( $\mathrm{p}>0.05)$.

\section{TARTIŞMA ve SONUÇ}

$\mathrm{Bu}$ araştırmanın temel amacı sınıflarında kaynaştırma öğrencisi bulunan ve bulunmayan öğrencilerin bakış açısı alma becerilerini belirlemektir. Araştırma sonucunda, kaynaştırma öğrencisi bulunan sınıftaki çocuklar ile kaynaştırma öğrencisi bulunmayan sınıftaki çocukların bakış açısı alma becerisinin birbirinden farklı olmadığı belirlenmiştir. Piaget'nin (2004) Zihinsel Gelişim Kuramına göre okul öncesi dönemdeki çocukların benmerkezci olduğu bilinmektedir. Benmerkezci dönemde çocuklar, başkalarının kendisinden farklı bir bakış açısına sahip olabileceklerini fark edememektedirler. Dolayısıyla, kaynaştırma öğrencisi olan ve olmayan sınıftaki çocukların arasında bakış açısı alma becerileri bakımından fark olmamasının nedeninin bu çocukların hepsinin benmerkezci dönemde olmalarından kaynaklandığı düşünülmektedir. Bununla birlikte sınıfında kaynaştırma öğrencisi bulunan öğretmenlerin normal gelişim gösteren öğrencilerle yapmış olabilecekleri kaynaştırmaya hazırlık etkinlikleri de her iki grubun bakış açısı alma puanlarında farklılığa yol açmış olabilir. Örneğin Koçyiğit (2015) araştırmasında, sınıfında kaynaştırma öğrencisi olan öğretmenlerin, kaynaştırma öğrencisinin kabulü için kaynaştırma öğrencisinin özelliklerini içeren farklı öyküler hazırladıklarını, bu öyküleri çocukların canlandırmalarını sağladıklarını ve böylece empati kurmalarına yardımcı olmak için drama etkinlikleri gerçekleştirdiklerini belirlemiştir. Nitekim Batu ve Kurcaali İftar (2006) öğrencilerin kendilerini özel gereksinimli öğrencinin yerine koyarak empati kurmalarını 
sağlayacak canlandırma çalışmalarını, normal gelişim gösteren öğrencilerin kaynaştırma eğitimine hazırlanması açısından önemli görmektedir.

Çocukların bakış açısı alma becerilerinin cinsiyete göre farklılaşmadı̆̆ belirlenmiştir. Bu sonuca göre erkek ve kız öğrencilerinin bakış açısı alma becerilerinin benzer olduğu görüşüne varılabilir. Literatürde de erken çocukluk döneminde okulöncesi dönemdeki çocukların bakış açısı alma becerileri arasında cinsiyete göre fark olmadığına yönelik çalışmalar bu bulguyu destekler niteliktedir (Gültekin, 2006; Oğuz, 2006; Ünüvar, 2006; Bal ve Temel, 2014; Frick, Möhring ve Newcombe, 2014; Y1ldız ve Güney Karaman, 2017).

Çocukların bakış açısı alma becerilerinin yaşa göre incelenmesi sonucunda, yaş arttıkça bakış açısı alma becerisinin de artış gösterdiği ve özellikle 4 yaş grubunun 5 ve 6 yaşa göre bakış açısı alma becerisinde daha geri oldukları görülmektedir. Bu durumun nedeninin, yaş ilerledikçe çocukların benmerkezci dönemi geride bırakıp, çevrelerinin genişlemesi ve daha fazla kişiyle iletişim kurmaya başlamaları, deneyimlerin artması ve düşünme becerilerinin gelişmesi olduğu düşünülmektedir. Gülay ve Akman (2009) yaş arttıkça, çocukların iletişim ve etkileşim kurdukları kişi sayısının çoğaldığını dolayısıyla sosyal çevresinin genişlediğini, deneyimlerinin arttığını, ben merkezlilikten uzaklaştıklarını ve zihinsel becerilerinin geliştiğini belirtmişlerdir. Sosyal çevrenin gelişmesi sonucunda, içinde yaşadıkları toplumu ve bu toplumu oluşturan insanları tanımak için daha fazla olanağa sahip olmaktadırlar. Dolayısıyla bu durumun başka insanların duygularına ve düşüncelerine daha duyarlı olabilmelerine de neden olabileceğini de ifade etmişlerdir. Bal ve Temel (2014), 4- 6 yaş grubu okul öncesi dönem çocuklarının yaşları arttıkça problem çözme ve bakış açısı alma becerilerinin de arttığını saptamışlardır. Köksal Akyol ve Aslan (2014), okul öncesi dönem çocuklarının bakış açısı alma ve empati becerileri arasında anlamlı bir ilişki olduğunu ve çocukların empati becerilerinin yaş ile birlikte arttığını saptamışlardır.

\section{ÖNERÍLER}

Bu sonuçlar 1şı̆̆ında aşağıdaki öneriler getirilmiştir:

Çocukların bakış açısı alma becerilerinin geliştirilebilmesi için sınıf içinde özellikle çocukların empati ve bakış açısı alma becerilerini geliştirmeye yönelik grup rehberliği etkinliklerine yer verilmelidir. Öğretmenlerin bakış açısı alma ve empatik iletişim kurma konularında çocuklara doğru rol model olmaları gerekmektedir. Empati veya bakış açısı alma eğitim programları hakkında okulöncesi öğretmenlerinin eğitim alabileceği hizmet içi eğitim seminerleri düzenlenebilir.

İlerideki araştırmalara yönelik olarak ise, bu araştırma kaynaştırma öğrencisi bulunan sınıftaki çocuklar ile kaynaştırma öğrencisi bulunmayan sınıftaki çocukların bakış açısı alma becerilerini karşılaştırmak ile sınırlıdır. Kaynaştırma öğrencisi bulunan sınıftaki çocuklar ile kaynaştırma öğrencisi bulunmayan sınıftaki çocukların bakış açısı alma becerisi ile birlikte empati becerilerinin farklı değişkenlerle ele alındığı yeni çalışmalar planlanabilir. Kaynaştırma öğrencisi bulunan sınıftaki çocukların kaynaştırma eğitimine dahil olma nedenleri (işitme, görme, öğrenme güçlüğü, hiperaktiflik, otizmli) sorulmamıştır. İleride yapılacak araştırmalarda, kaynaştırma alma nedenlerinin de dahil edilip (örneğin; bedensel engelli bir öğrencinin olduğu sınıflarda) bakış açısı alma becerisine etkilerinin incelendiği yeni çalışmalar planlanabilir. 


\section{KAYNAKÇA}

Akbulut, Y. (2010). Sosyal bilimlerde Spss uygulamaları. İstanbul: Ideal Yayıncılık.

Arslan, E. (2010). Kaynaştırma uygulamalarına katılan engelli öğrencilerin sosyal kabul düzeylerinin belirlenmesine yönelik ölçek geliştirme çabası, Yayımlanmamış Yüksek Lisans Tezi. Mehmet Akif Ersoy Üniversitesi, Sosyal Bilimler Enstitüsü, Burdur.

Aslan, D. ve Köksal Akyol, A. (2016). Çocuklar için Bakış Açısı Alma Testi (ÇBT)'nin geliştirilmesi, Ahi Evran Üniversitesi Kırşehir Eğitim Fakültesi Dergisi (KEFAD), 17 (3), 207-221.

Bal, Ö. ve Temel, A. F. (2014). Okul öncesi eğitim kurumlarına devam eden 4- 6 yaş çocuklarının kişilerarası problem çözme ve bakış açısı alma becerileri arasındaki ilişkinin incelenmesi, Trakya Üniversitesi. Eğitim Fakültesi Dergisi, 4 (1), 156-169.

Baron-Cohen, S. (1989). The autistic child's theory of mind: A case of specific developmental delay. Journal of Child Psychiatry, 30, 285-297.

Baskerville, D. (2011). Developing cohesion and building positive relationships through storytelling in a culturally diverse New Zealand classroom. Teaching and Teacher Education, 27, 107-115.

Batu, S., Kırcaali İftar, G. ve Uzuner, Y. (2004). Özel gereksinimli öğrencilerin kaynaştırıldığı bir kız meslek lisesindeki öğretmenlerin kaynaştırmaya ilişkin görüş ve önerileri, Ankara Üniversitesi Eğitim Bilimleri Fakültesi Özel Eğitim Dergisi, 5 (2), 33-50.

Batu, S. ve Kırcaali İftar, G. (2006). Kaynaştırma. Ankara: Kök Yayıncılık.

Bek, H., Gülveren, H. ve Başer, A. (2009). Sınıf öğretmeni adaylarının kaynaştırma eğitimine yönelik tutumlarının incelenmesi. Uşak Üniversitesi Sosyal Bilimler Dergisi, 2 (2), 160-168.

Büyüköztürk, Ş. (2002). Sosyal bilimler için veri analizi el kitabl. Ankara: Pegem Akademi.

Civelek, A. H. (1990). Eğitilebilir zihinsel özürlü çocukların sosyal kabul görmelerinde normal çocukların bilgilendirilmelerinin ve iki grubun resim iş ile beden eğitimi derslerinde bütünleştirilmelerinin etkileri. Yayımlanmamış Doktora Tezi, Ankara Üniversitesi Sosyal Bilimler Enstitüsü, Ankara.

Diamond, K., and Hestenes, L. (1996). Preschool children's conceptions of disabilities: the salience of disability in children's ideas about others. Topics in Early Childhood Special Education, 16, 458-475.

Dixion, A. J., and Moore, F. C. (1990). The development of perspective taking: Understanding differences in information and weighting. Child Development, 61, 1502- 1513.

Dökmen, Ü. (2013). Sanatta ve günlük yaşamda iletişim çatışmaları ve empati, İstanbul: Remzi Kitabevi.

Ersoy. Ö. ve Avc1, N. (2000). Özel gereksinimi olan çocuklar ve eğitimleri-Özel eğitim. İstanbul: Ya-Pa Yayınları.

Essa, E. (1999). A practical guide to solving preschool behaviour problems, (4th edition, pp 28). Nevada: Delmar Publishers.

Frick, A., Möhring, W. and Newcombe, N.S. (2014) Picturing perspectives: Development of perspective-taking abilities in 4- to 8-year-olds. Frontiers Psychology, 5 (386),1-7,. doi: 10.3389/fpsyg.2014.00386

Galinsky, A. D., Ku, G. and Wang, C. S. (2005). Perspective taking and self-other overlap: Fostering social bonds and facilitating social coordination. Group Process and Intergroup Relations, 8, 109-124. doi:10.1177/1368430205051060

Galinsky, A. D. and Moskowitz, G. B. (2000). Perspective-taking: Decreasing stereotype expression, stereotype accessibility, and in-group favoritism. Journal of Personality and Social Psychology, 78 (4), 708-724. http://dx.doi.org/10.1037/0022-3514.78.4.708

Göksu, İ. ve Çevik, T. (2004). Özel ĕgitime giriş, Adana.

Gülay, H. ve Akman, B. (2009). Okul öncesi dönemde sosyal beceriler. Ankara: Pegem Yayıncılık.

Gültekin, A. (2006). Anaokuluna devam eden 6 yaşındaki çocukların başkalarının bakış açısını alma becerisi ile özsaygı düzeyleri arasındaki ilişkinin incelenmesi. Yayımlanmamış Yüksek Lisans Tezi, Gazi Üniversitesi, Eğitim Bilimleri Enstitüsü, Çocuk Gelişimi ve Eğitimi Anabilim Dalı, Ankara.

Gürtunca, A. (2013). Çocuklar ve ergenler için empati ölçeği Türkiye geçerlik ve güvenilirlik çalışması, Yayımlanmamış Yüksek Lisans Tezi, İstanbul Arel Üniversitesi, Sosyal Bilimler Enstitüsü, İstanbul.

Heagle, A. I., and Rehfeldt, R. A. (2006). Teaching perspective-taking skills to typically developing children through derived relational responding. Journal of Early and Intensive Behavior Intervention, 3(1), 1-34.

Huneryager, S.G., and Heckman, I.L. (1967). Human relation in management, Second edition, South-Western Publishing Company.

Karasar, N. (2002). Bilimsel araştırma yöntemleri, Ankara: Nobel Yayın Dağıtım.

Keski, Y. ve Aykaç, M. (2014). İletişim engellerinin aile içi iletişime etkisini incelemede yaratıcı drama yönteminin kullanımına ilişkin katılımcı görüşleri, Turkish Journal Of Social Research/Türkiye Sosyal Arastırmalar Dergisi, 18 (3), 121-144.

Kırcaali-İftar, G. (1998). Özel ĕgitim kaynaştırma ve destek özel ĕgitim hizmetleri. Eskişehir: Anadolu Üniversitesi Açıköğretim Fakültesi Yayınları. No: 561.

Kırcaali-İftar, G. ve Batu, S. (2005). Kaynaştırma. Ankara: Kök Yayıncılık.

Koçyiğit, S. (2015). Ana sınıflarında kaynaştırma eğitimi uygulamalarına ilişkin öğretmen-rehber öğretmen ve ebeveyn görüşleri, Uluslararası Türkçe Edebiyat Kültür Eğitim Dergisi, 4 (1), 391-415. 
Köksal Akyol, A. ve Aslan, D. (2014). The development of the empath scale for children (ESC). In M. Yasar, O. Ozgun, \& J. Galbraith (Eds.),Contemporary Perspectives and Research on Early Childhood Education (pp.113-123). Newcastle: Cambridge Scholar Publishing.

Kubota, J.T. and Ito, T.A. (2014). The role of expression and race in weapons identification. Emotion,14 (6), $1115-$ 1124. http://dx.doi.org/10.1037/a0038214

Maine, F. (2013). How children talk together to make meaning from texts: A dialogic perspective on reading comprehension strategies, Literacy, 47, 150-156.

MEB (2018). Özel eğitim hizmetleri yönetmeliği, $(7 \quad$ Temmuz 2018), http://orgm.meb.gov.tr/meb_iys_dosyalar/2018_07/09101900_ozel_egitim_hizmetleri_yonetmeligi_0707201 8.pdf.

Metin, N. (2012). Özel gereksinimli çocukların kaynaştırılması. (Ed. N. Metin), Özel gereksinimli çocuklar, Ankara: Maya Akademi.

Muslu-Köseoğlu, S. (1994). Psikolojik Danışmanların Empatik Becerilerinin ve Kişilik Özelliklerinin İncelenmesi, Yayımlanmamış Yüksek Lisans Tezi, Marmara Üniversitesi, Sosyal Bilimler Enstitüsü, İstanbul.

Oğuz, V. (2006). Altı yaş grubundaki çocukların bakış açısı alma becerileri ile anne babaların empatik becerilerinin incelenmesi. Yayımlanmamış Yüksek Lisans Tezi. Ankara Üniversitesi Fen Bilimleri Enstitüsü, Ev Ekonomisi (Çocuk Gelişimi ve Eğitimi) Anabilim Dalı, Ankara.

Özbek, M. F. (2004). Toplumsal yaşamda empati, Akademik Bakış Uluslararası Hakemli Sosyal Bilimler E-Dergisi, 1, 1-16.

Özdamar, K. (2004). Paket programlar ile istatiksel veri analizi-1. Eskişehir: Kaan Kitabevi.

Piaget, J. (2004). Çocukta zihinsel gelişim, (Çev: H. Portakal). İstanbul: Cem Yayınevi.

Roberts, W., and Strayer, J. (1996) Empathy, emotional expressiveness and prosocial behavior, Child Development, 67, 449- 470.

Salı, G. (2013). İlköğretim ikinci kademedeki çocukların empatik eğilimlerinin ve benlik kavramlarının incelenmesi, Kuramsal Ë̆itimbilim Dergisi, 6 (4), 496-519.

Specht, J. A. (2013). Mental health in schools: Lessons learned from exclusion. Canadian Journal of School Psychology, 28, 43-55

Sucuoğlu, B. ve Kargın, T. (2008). Illkögrretimde kaynaştırma uygulamaları: Yaklaşımlar, yöntemler, teknikler. İstanbul: Morpa Yayıncilık.

Şener, T. (1996). 4-5 yaş anaokulu çocuklarında dramatik oyunun ve inşa oyununun bakış açısı alma becerisine etkisi. Yayımlanmamış Yüksek Lisans Tezi, Ankara Üniversitesi, Ankara.

Turgut, Y. (2012). Verilerin kaydedilmesi, analizi, yorumlanması: Nicel ve nitel. A. Tanriögren (Ed.), Bilimsel araştırma yöntemleri (s.192-248). Ankara: Anı Yayıncılık.

Ünüvar, G. (2006). Okulöncesi eğitim kurumlarına devam eden 4- 5 yaş çocuklarında zenginleştirilmiş Türkçe dil etkinliklerinin bakış açısı alma becerisine ve ifade edici dil düzeylerine etkisinin incelenmesi. Yayımlanmamış Yüksek Lisans Tezi. Selçuk Üniversitesi. Sosyal Bilimler Enstitüsü, Konya.

Villa, A. R., and Thousand, S. J. (2005). Creating an inclusive school, 2nd edition, Alexandria, VA: Association for Supervision and Curriculum Development.

Yüksel, A. (2004). Empati eğitim programının ilköğretim öğrencilerinin empatik becerilerine etkisi, Uludă̆ Üniversitesi Eğitim Fakültesi Dergisi, XVII (2), 341-354. 